\title{
Growth performance of Asian seabass Lates calcarifer (Bloch, 1790) stocked at varying densities in floating cages in Godavari Estuary, Andhra Pradesh, India
}

\author{
SHUBHADEEP GHOSH, SEKAR MEGARAJAN, RITESH RANJAN, BISWAJIT DASH, \\ PHALGUNI PATTNAIK, LOVESON EDWARD AND BIJI XAVIER \\ Visakhapatnam Regional Centre of ICAR-Central Marine Fisheries Research Institute \\ Visakhapatnam - 530 003, Andhra Pradesh, India \\ e-mail: subhadeep_1977@yahoo.com
}

\begin{abstract}
Present study was undertaken in Godavary Estuary, Andhra Pradesh for evaluation of the effect of three stocking densities on growth performance, survival and production of Lates calcarifer (Bloch, 1790) in floating cages and for optimisation of stocking density in cage farming. Seabass fingerlings having length and weight of $8.36 \pm 0.32 \mathrm{~cm}$ and $8.10 \pm 0.61 \mathrm{~g}$ respectively, were stocked in six cages ( $6 \mathrm{~m}$ dia; $3 \mathrm{~m}$ net depth) at three different stocking densities of 15,30 and 45 nos. $\mathrm{m}^{-3}$ and their growth performance was monitored every fortnight for five months. All fishes were fed with chopped trash fish (a) $8-12 \%$ of body weight. After 150 days of grow-out culture, seabass fingerlings reached $36.0 \pm 6.0 \mathrm{~cm}$ in length and $690.7 \pm 41.3 \mathrm{~g}$ in weight at density of $15 \mathrm{nos} . \mathrm{m}^{-3}, 33.9 \pm 0.4 \mathrm{~cm}$ and $633.2 \pm 17.9 \mathrm{~g}$ at density of $30 \mathrm{~m}^{-3}$ and $30.2 \pm 0.4 \mathrm{~cm}$ and $465.0 \pm 21.2 \mathrm{~g}$ at density of 45 nos. $\mathrm{m}^{-3}$. Growth was allometric and did not differ with stocking density. Survival percentage was comparatively higher at lower $(87.3 \%)$ and moderate $(83.9 \%)$ stocking densities, while production was higher at moderate $(1363.2 \mathrm{~kg})$ and higher $(1258.4 \mathrm{~kg})$ stocking densities $(\mathrm{p}<0.5)$. Gain in weight as well as specific growth rate (SGR) were higher at lower and moderate stocking densities $(\mathrm{p}<0.5)$. The results of the study indicated that among the three stocking densities tested, 30 nos. $\mathrm{m}^{-3}$ is superior to 15 and 45 nos. $\mathrm{m}^{-3}$, with higher yield.
\end{abstract}

Keywords: Cage culture, Growth, Lates calcarifer, Production, Stocking density, Survival

Mariculture offers great potential for augmenting marine fish production and cage farming is considered to be the most productive method among all the available mariculture technologies. Asian seabass Lates calcarifer (Bloch, 1790) is one of the most promising candidate species for mariculture, with its fast growth rate, high feed conversions, tolerance to wide environmental conditions and its sustained demand in both domestic and export markets (Rao et al., 2013). In India, culture of seabass in floating cages has been attempted by many workers (Anil et al., 2010; Joseph et al., 2010; Mojjada et al., 2012; Philipose et al., 2013a). Apart from the work of Sakaras (1987), there are no reports till date on optimisation of stocking density for cage farming of seabass. The present study was designed to evaluate the effect of different stocking densities on the growth performance of seabass cultured in cages in Godavari Estuary at Narsapur, Andhra Pradesh, India and to arrive at optimum stocking density for seabass farming in cages installed in river mouth or estuary.

Cage site near Narsapur ( $16^{0} 20^{\prime} 01.8$ " N; 81043'05.3” E) in Godavari Estuary, with water depth of $6 \mathrm{~m}$ and tidal amplitude of $2 \mathrm{~m}$, was selected for the study. Six circular indigenously designed and fabricated galvanised iron (GI) cages of $6 \mathrm{~m}$ dia and $3 \mathrm{~m}$ net depth were installed. Cages were connected to HDPE outer predator (braided $60 \mathrm{~mm}$ ), inner grow-out $(20 \mathrm{~mm})$ and bird $(80 \mathrm{~mm})$ nets and were moored $10 \mathrm{~m}$ apart from each other. Twenty thousand seabass fry $(4.8 \pm 0.2 \mathrm{~cm}$ in length and $1.2 \pm 0.1 \mathrm{~g}$ in weight) procured from the hatchery of the Rajiv Gandhi Centre for Aquaculture (RGCA) at Sirkazhi, Tamil Nadu, India were transported, acclimatised and nursed in hapas for 38 days at a density of 463 nos. $\mathrm{m}^{-3}$, yielding a survival of $77 \%$. Fingerlings (15408 nos., mean length $8.36 \pm 0.32 \mathrm{~cm}$; mean weight $8.10 \pm 0.61 \mathrm{~g})$ harvested from the hapas, were released randomly into six cages. The stocking density followed was 1284 nos. cage ${ }^{-1}\left(15\right.$ nos. $\left.\mathrm{m}^{-3}\right), 2568$ nos. cage ${ }^{-1}\left(30\right.$ nos. $\left.\mathrm{m}^{-3}\right)$ and 3852 nos.cage ${ }^{-1}\left(45\right.$ nos. $\left.\mathrm{m}^{-3}\right)$ in duplicates. Stocking densities ranging from 10 to 35 nos. $\mathrm{m}^{-3}$ are most commonly used in seabass grow-out systems in cages (Kungvankij et al., 1984; Cheong, 1989; Anil et al., 2010; Joseph et al., 2010; Mojjada et al., 2012; Philipose et al., 2013a). Feeding strategy was similar in all the cages. The fishes were fed initially thrice, which was later reduced to twice a day with fresh or frozen chopped trash fish (tilapia). Feeding regime followed was: $12 \%$ of body weight at 10 to $100 \mathrm{~g}$ size range, $10 \%$ at $100-300 \mathrm{~g}$ size and $8 \%$ at more than $300 \mathrm{~g}$. Periodical 
sampling of fishes was carried out once in every fortnight and important growth parameters viz., weight gain (\%), weight increment per day $(\mathrm{g})$ and specific growth rate (SGR) were estimated. Length-weight relationship, $W=\mathrm{a} L^{\mathrm{b}}$ was calculated separately for the three stocking densities. Water samples were collected fortnightly from the cage area and analysed for temperature, $\mathrm{pH}$, dissolved oxygen, ammonia and nitrite (APHA, 1989). Fishes were harvested after 5 months of grow-out and the total production and survival were recorded.

Analysis of variance (ANOVA) followed by post-hoc Tukey test was done to study the differences in growth parameters, survival and production at $5 \%$ probability level and to make comparisons on the effect of varying stocking densities, using SPSS software, version 16.0 (SPSS, Inc., Chicago, IL, USA). Significant differences in the slopes of the regression lines of length-weight relation were ascertained by analysis of covariance (ANCOVA) and Student's t-test was performed to check the nature of growth.

There was no signs of disease/stress or water quality deterioration observed during regular sampling throughout the culture period. Water quality parameters were within the limits as recommended by Rimmer and Russel (1998) and Schipp et al. (2007) for the grow-out culture of seabass. Salinity ranged from 17.6 to $28.4 \mathrm{gl}^{-1}\left(23.5 \pm 1.0 \mathrm{gl}^{-1}\right)$, temperature from 29.4 to $31.3^{\circ} \mathrm{C}\left(30.4 \pm 0.3^{\circ} \mathrm{C}\right)$, $\mathrm{pH}$ from 7.8 to $8.4(8.0 \pm 0.1)$, dissolved oxygen level from 4.0 to $4.5 \mathrm{mg} \mathrm{l}^{-1}\left(4.3 \pm 0.2 \mathrm{mg} \mathrm{l}^{-1}\right)$, ammonia-nitrogen from 0.002 to $0.007 \mathrm{mg} \mathrm{l}^{-1}\left(0.005 \pm 0.001 \mathrm{mg} \mathrm{l}^{-1}\right)$ and nitrite-nitrogen from 0.008 to $0.015 \mathrm{mg} \mathrm{l}^{-1}\left(0.010 \pm 0.002 \mathrm{mgl}^{-1}\right)$.

Fingerlings of seabass, having mean length and weight of $8.36 \pm 0.32 \mathrm{~cm}$ and $8.10 \pm 0.61 \mathrm{~g}$ respectively after stocking in cages at three different densities, reached on an average $36.0 \pm 6.0 \mathrm{~cm}$ and $690.7 \pm 41.3 \mathrm{~g}$ at density of 15 nos. $\mathrm{m}^{-3}, 33.9 \pm 0.4 \mathrm{~cm}$ and $633.2 \pm 17.9 \mathrm{~g}$ at density of 30 nos. $\mathrm{m}^{-3}$ and $30.2 \pm 0.4 \mathrm{~cm}$ and $465.0 \pm 21.2 \mathrm{~g}$ at density of
45 nos. $\mathrm{m}^{-3}$, after five months of culture. Growth performance in terms of average weight recorded at regular intervals of 15 days at each of the three densities is depicted in Fig. 1. Length-weight relationship derived for the farmed seabass at the lower, moderate and higher stocking densities were $\mathrm{W}=0.000008 \mathrm{~L}^{3.12} ; \mathrm{W}=0.000004 \mathrm{~L}^{3.27}$ and $\mathrm{W}=0.000003 \mathrm{~L}^{3.24}$; respectively. There were no significant differences in the length-weight relation between the three stocking densities. The slope of regression relation varied significantly $(p<0.5)$ from the isometric value of 3 , indicating allometric growth in all the stocking densities. Similar relationships were reported for Asian seabass by Rodgers (1996) from ponds, Volvich and Appelbaum (2001) from recirculating tanks and Philipose et al. (2013b) from offshore cages.

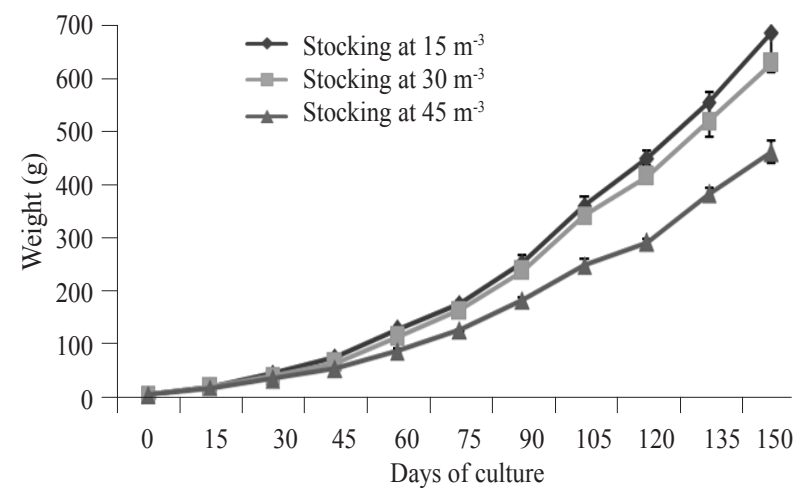

Fig. 1. Weight of seabass (Mean \pm SE) stocked in cages at varying densities

Weight gain, weight increment per day and SGR on days $15,30,45,60,75,90,105,120,135$ and 150 are presented in Tables 1 and 2. On termination of the experimental farming, weight gain percentage was higher at the lower $(8427.6 \pm 509.8)$ and moderate $(7716.7 \pm 220.8)$ stocking densities and was lower at the higher $(5640.8 \pm 261.5)$ stocking density $(\mathrm{p}<0.5)$. Similarly, higher weight increment per day was also recorded in the lower $(4.6 \pm 0.3 \mathrm{~g})$ and moderate $(4.2 \pm 0.1 \mathrm{~g})$ stocking

Table 1. Weight gain and increment (Mean $\pm \mathrm{SE})$ of seabass stocked in cages at varying densities

\begin{tabular}{|c|c|c|c|c|c|c|}
\hline \multirow{2}{*}{ Days of culture } & \multicolumn{3}{|c|}{ Weight gain (\%) } & \multicolumn{3}{|c|}{ Weight increment per day (g) } \\
\hline & Density $15 \mathrm{~m}^{-3}$ & Density $30 \mathrm{~m}^{-3}$ & Density $45 \mathrm{~m}^{-3}$ & Density $15 \mathrm{~m}^{-3}$ & Density $30 \mathrm{~m}^{-3}$ & Density $45 \mathrm{~m}^{-3}$ \\
\hline 15 & $192.1 \pm 6.4^{\mathrm{a}}$ & $167.4 \pm 5.9^{\mathrm{ab}}$ & $141.9 \pm 8.1^{\mathrm{b}}$ & $1.04 \pm 0.03^{\mathrm{a}}$ & $0.90 \pm 0.03^{\mathrm{ab}}$ & $0.77 \pm 0.04^{\mathrm{b}}$ \\
\hline 30 & $489.6 \pm 11.4^{\mathrm{a}}$ & $438.6 \pm 12.8^{\mathrm{ab}}$ & $371.0 \pm 14.8^{\mathrm{b}}$ & $1.32 \pm 0.03^{\mathrm{a}}$ & $1.18 \pm 0.03^{\mathrm{ab}}$ & $1.00 \pm 0.04^{\mathrm{b}}$ \\
\hline 45 & $873.0 \pm 64.0^{\mathrm{a}}$ & $736.9 \pm 18.2^{\mathrm{a}}$ & $606.9 \pm 38.4^{\mathrm{a}}$ & $1.57 \pm 0.12^{\mathrm{a}}$ & $1.33 \pm 0.03^{\mathrm{a}}$ & $1.09 \pm 0.07^{\mathrm{a}}$ \\
\hline 60 & $1512.8 \pm 70.3^{\mathrm{a}}$ & $1349.1 \pm 79.9^{\mathrm{a}}$ & $1015.9 \pm 52.7^{\mathrm{b}}$ & $2.04 \pm 0.09^{\mathrm{a}}$ & $1.82 \pm 0.11^{\mathrm{ab}}$ & $1.37 \pm 0.07^{\mathrm{b}}$ \\
\hline 75 & $2119.1 \pm 49.0^{\mathrm{a}}$ & $1970.1 \pm 25.6^{\mathrm{a}}$ & $1501.5 \pm 19.9^{b}$ & $2.29 \pm 0.05^{\mathrm{a}}$ & $2.13 \pm 0.03^{\mathrm{a}}$ & $1.62 \pm 0.02^{\mathrm{b}}$ \\
\hline 90 & $3069.3 \pm 186.2^{\mathrm{a}}$ & $2887.2 \pm 124.9^{\mathrm{ab}}$ & $2197.0 \pm 74.9^{\mathrm{b}}$ & $2.76 \pm 0.17^{\mathrm{a}}$ & $2.60 \pm 0.11^{\mathrm{ab}}$ & $1.98 \pm 0.07^{\mathrm{b}}$ \\
\hline 105 & $4408.0 \pm 192.9^{\mathrm{a}}$ & $4174.8 \pm 153.9^{\mathrm{a}}$ & $3006.7 \pm 154.4^{b}$ & $3.40 \pm 0.15^{\mathrm{a}}$ & $3.22 \pm 0.12^{\mathrm{a}}$ & $2.32 \pm 0.12^{\mathrm{b}}$ \\
\hline 120 & $5507.5 \pm 171.4^{\mathrm{a}}$ & $5080.7 \pm 187.8^{\mathrm{a}}$ & $3541.3 \pm 91.3^{\mathrm{b}}$ & $3.72 \pm 0.12^{\mathrm{a}}$ & $3.43 \pm 0.13^{\mathrm{a}}$ & $2.39 \pm 0.06^{\mathrm{b}}$ \\
\hline 135 & $6804.8 \pm 251.1^{\mathrm{a}}$ & $6373.3 \pm 363.7^{\mathrm{a}}$ & $4674.0 \pm 145.7^{\mathrm{b}}$ & $4.08 \pm 0.15^{\mathrm{a}}$ & $3.82 \pm 0.22^{\mathrm{a}}$ & $2.80 \pm 0.09^{b}$ \\
\hline 150 & $8427.6 \pm 509.8^{a}$ & $7716.7 \pm 220.8^{\mathrm{ab}}$ & $5640.8 \pm 261.5^{b}$ & $4.55 \pm 0.28^{\mathrm{a}}$ & $4.17 \pm 0.12^{\mathrm{ab}}$ & $3.05 \pm 0.14^{b}$ \\
\hline
\end{tabular}

Mean values for each growth parameter with different superscripts between columns in each row for each day indicate significant ( $<<0.05$ ) differences between three stocking densities; Gain (\%) and increment on each day of culture was computed from 0 day 
Table 2. Specific growth rate (Mean \pm SE) of seabass stocked in cages at varying densities

\begin{tabular}{llll}
\hline \multirow{2}{*}{$\begin{array}{l}\text { Days of } \\
\text { culture }\end{array}$} & \multicolumn{3}{c}{ Specific growth rate (SGR) } \\
\cline { 2 - 4 } & Density $15 \mathrm{~m}^{-3}$ & Density $30 \mathrm{~m}^{-3}$ & Density $45 \mathrm{~m}^{-3}$ \\
\hline 15 & $7.14 \pm 0.15^{\mathrm{a}}$ & $6.56 \pm 0.15^{\mathrm{ab}}$ & $5.89 \pm 0.22^{\mathrm{b}}$ \\
30 & $5.91 \pm 0.06^{\mathrm{a}}$ & $5.61 \pm 0.08^{\mathrm{ab}}$ & $5.16 \pm 0.10^{\mathrm{b}}$ \\
45 & $5.05 \pm 0.15^{\mathrm{a}}$ & $4.72 \pm 0.05^{\mathrm{ab}}$ & $4.34 \pm 0.12^{\mathrm{b}}$ \\
60 & $4.63 \pm 0.07^{\mathrm{a}}$ & $4.45 \pm 0.09^{\mathrm{ab}}$ & $4.02 \pm 0.08^{\mathrm{b}}$ \\
75 & $4.13 \pm 0.03^{\mathrm{a}}$ & $4.04 \pm 0.02^{\mathrm{a}}$ & $3.70 \pm 0.02^{\mathrm{b}}$ \\
90 & $3.84 \pm 0.07^{\mathrm{a}}$ & $3.77 \pm 0.05^{\mathrm{ab}}$ & $3.48 \pm 0.04^{\mathrm{b}}$ \\
105 & $3.63 \pm 0.04^{\mathrm{a}}$ & $3.58 \pm 0.03^{\mathrm{a}}$ & $3.27 \pm 0.05^{\mathrm{b}}$ \\
120 & $3.36 \pm 0.03^{\mathrm{a}}$ & $3.29 \pm 0.03^{\mathrm{a}}$ & $3.00 \pm 0.02^{\mathrm{b}}$ \\
135 & $3.14 \pm 0.03^{\mathrm{a}}$ & $3.09 \pm 0.04^{\mathrm{a}}$ & $2.86 \pm 0.02^{\mathrm{b}}$ \\
150 & $2.96 \pm 0.04^{\mathrm{a}}$ & $2.91 \pm 0.02^{\mathrm{a}}$ & $2.70 \pm 0.03^{\mathrm{b}}$ \\
\hline
\end{tabular}

Mean values with different superscripts between columns in each row for each day indicate significant $(\mathrm{p}<0.05)$ differences between three stocking densities; SGR on each day of culture was computed from 0 day

densities $(\mathrm{p}<0.5)$. SGR after 150 days, was $2.7,2.9$ and 3.0 in the highest, moderate and lower stocking densities $(p<0.5)$ respectively. Daily weight increment increased progressively with increase in culture period. During the first 15 days of culture (from 0 to $15^{\text {th }}$ day), weight gain for each day varied from 0.8 to $1.0 \mathrm{~g}$, whereas during the last 15 days of culture (from $136^{\text {th }}$ to $150^{\text {th }}$ day) daily weight gain varied from 5.2 to $8.8 \mathrm{~g}$. SGR was higher during the initial months of culture and decreased gradually towards the end of the culture. Jobling (1994) reported an inverse relationship between SGR and fish weight and the results of the present study are in full agreement with this. The changing pattern of growth parameters with culture duration was similar at all the three stocking densities. Average gain and increments in body weight was consistent with earlier reports on cage cultured seabass in different environments using different feeds (Sakaras, 1987; Eusebio and Coloso, 2000; Katersky and Carter, 2005; Anil et al., 2010; Joseph et al., 2010; Mojjada e al., 2012; Philipose et al., 2013a). SGR was higher than that reported by many authors (Anil et al., 2010; Joseph et al., 2010; Mojjada et al., 2012). Seabass reared at moderate to lower densities were fed well on the trash fishes and shoaling behaviour during feeding was observed. Shoaling behaviour resulted in active feeding by all fishes following each other, which might have accounted for the higher growth rate obtained in the present study.

Significantly $(p<0.5)$ higher survival percentages for lower and moderate stocking densities and higher production for moderate and higher stocking densities were observed. Highest survival of $87.3 \pm 0.7 \%$ was observed in the lowest stocking density, followed by $83.9 \pm 1.4 \%$ in the moderate stocking density and $70.3 \pm 1.7 \%$ in the highest stocking density. Survival at densities of 15 and $30 \mathrm{~m}^{-3}$, were higher in comparison to 20 to $80 \%$ reported in cage cultured seabass by Anil et al. (2010), Joseph et al. (2010) and Mojjada et al. (2012). Poor survival recorded at higher stocking density could be because of loss of appetite due to crowding stress, resulting in reduced feed consumption and differential growth rate with subsequent development of shooters and resultant cannibalism. The moderate stocking density recorded the highest production of $1363.2 \pm 16.2 \mathrm{~kg}$ $\left(16.04 \pm 0.19 \mathrm{~kg} \mathrm{~m}^{-3}\right)$, followed by $1258.4 \pm 26.4 \mathrm{~kg}$ $\left(14.80 \pm 0.31 \mathrm{~kg} \mathrm{~m}^{-3}\right)$ and $773.7 \pm 40.3 \mathrm{~kg}\left(9.10 \pm 0.47 \mathrm{~kg} \mathrm{~m}^{-3}\right)$ in the higher and lower stocking densities respectively. Body weight and total production recorded after five months of culture is superior when compared to that reported earlier from cages by Sakaras (1987), Mackkinnon (1989), Schipp et al. (2007), Joseph et al. (2010) and Anil et al. (2010).

Growth and stocking density are closely linked (Coulibaly et al., 2007). Inter-individual contacts, competition for food and stress resulting from higher densities adversely affects the growth performance (Barcellos et al., 2004). In the present study, for cage cultured seabass, stocking density of 30 nos. $\mathrm{m}^{-3}$ was found to be better than the other two densities tested. Though growth performance and survival were marginally better in the lower stocking density of 15 nos. $\mathrm{m}^{-3}$, production was significantly less. At the higher stocking density of 45 nos. $\mathrm{m}^{-3}$, both growth performance and survival were significantly reduced. It is quite possible that at higher densities, with lack of space and water flow, fishes were stressed and their growth and survival was negatively affected.

\section{Acknowledgements}

The authors express their sincere thanks to the Director, ICAR-CMFRI, Kochi for the constant support and encouragement. The authors are highly indebted to Mr. V. Srinivasa Raju for his help in maintaining the cage farm.

\section{References}

APHA 1989. Standard methods for the examination of water and wastewater $12^{\text {th }}$ edn. American Public Health Association. New York, 769 pp.

Anil, M. K., Santosh, B., Jasmine, S., Saleela, K. N., George, R. M., Kingsley, H. J., Unnikrishnan, C., Rao, G. H. and Rao, G. S. 2010. Growth performance of the seabass Lates calcarifer (Blotch) in sea cage at Vizhinjam Bay along the south-west coast of India. Indian J. Fish., 57(4): 65-69.

Barcellos, L. J. G., Kreutz, L. C., Quevedo, M. R., Fioreze, I., Cericato, L., Soso, A. B., Fagundes, M., Conrad, J., Baldissera, R. K., Bruschi, A. and Ritter, F. 2004. Nursery rearing of Rhamdia quelen (Quoy and Gaimard) in cages: cage type, stocking density and stress response to confinement. Aquaculture, 232: 383-394. 
Cheong, L. 1989. Status of knowledge on farming of seabass (Lates calcarifer) in south-east Asia. Advances in Tropical Aquaculture, Tahiti, AQUACOP, IFREMER, Actes de Colloque, 9: 421-428.

Coulibaly, A., Ouattara, I. N., Kone, T., N'Douba, V., Snoeks, J., Bi, G. G. and Kouamelan, E. P. 2007. First results of floating cage culture of the African catfish Heterobranchus longifilis Valenciennes, 1840: Effect of stocking density on survival and growth rates. Aquaculture, 263: 61-67.

Eusebio, P. S. and Coloso, R. M. 2000. Nutritional evaluation of various plant protein sources in diets for Asian seabass Lates calcarifer. J. App. Ichthyol., 16: 56-60.

Jobling, M. 1994. Fish bioenergetics. Chapman and Hall, London, $309 \mathrm{pp}$.

Joseph, I., Joseph, S., Ignatius, B., Rao, G. S., Sobhana, K. S., Prema, D. and Varghese, M. 2010. A pilot study on culture of Asian seabass Lates calcarifer (Bloch) in open sea cage at Munambam, Cochin coast, India. Indian J. Fish., 57(3): 29-33.

Katersky, R. S. and Carter, C. G. 2005. Growth efficiency of juvenile barramundi, Lates calcarifer, at high temperatures. Aquaculture, 250(3-4): 775-780.

Kungvankij, P., Pudadera, B. J. Jr., Tiro, L. B. and Potestas, I. O. 1984. Biology and culture of seabass (Lates calcarifer). NACA Training Manual Series, 3: 67 pp.

Mackkinnon, M. R. 1989. Status and potential of Australian Lates calcarifer culture. Advances in Tropical Aquaculture, Tahiti, Feb 20 - March 4, 1989. AQUACOP IFREMER Actes de Colloque, 9: 713-727.

Mojjada, S. K., Joseph, I., Maheswarudu, G., Ranjan, R., Dash, B., Ghosh, S. and Rao, G. S. 2012. Open sea mariculture of Asian seabass Lates calcarifer (Bloch, 1790) in marine floating cage at Balasore, Odisha, north-east coast of India. Indian J. Fish., 59(3): 89-93.

Philipose, K. K., Krupesha Sharma, R. S., Loka, J., Divu, D., Sadhu, N. and Dube, P. 2013a. Culture of Asian seabass (Lates calcarifer, Bloch) in open sea floating net cages off Karwar, South India. Indian J. Fish., 60(1): 67-70.

Philipose, K. K., Divu, D., Krupesha Sharma, R. S., Vaidya, N. G., Sadhu, N. and Dube, P. 2013b. Length-weight relationship of Asian seabass, Lates calcarifer (Bloch) reared in open sea floating cages. Indian J. Fish., 60(1): 139-140.

Rao, G. S., Joseph, I., Philipose, K. K. and Mojjada, S. K. 2013 Cage aquaculture in India. Central Marine Fisheries Research Institute, Kochi, 233 pp.

Rimmer, M. A. and Russell, D. J. 1998. Aspects of the biology and culture of Lates calcarifer, In: De Silva, S. S. (Eds.), Tropical mariculture, Academic Press, USA, p. 449-476.

Rodgers, L. 1996. Feeds, feeders and feeding practices for the nursing of barramundi fry. Barramundi farming information package: Introductory information for prospective barramundi farmers. Freshwater Fisheries and Aquaculture Centre, Walkamin, Australia, p. 65-71.

Sakaras, W. 1987. Optimum stocking density of sea bass (Lates calcarifer) cultured in cages. In: Copland, J. W. and Grey, D. L. (Eds.), International Workshop on Management of wild and cultured seabass/barramundi (Lates calcarifer), Darwin, Australia, 24-30 September 1986. Australian Centre for International Agricultural Research, Canberra, Australia, 20:172-175.

Schipp, G., Bosmans, J. and Humphrey, J. 2007. Northern territory barramundi farming handbook. Department of Primary Industry, Fisheries and Mines, Australia, $71 \mathrm{pp}$.

Volvich, L. and Appelbaum, S. 2001. Length to weight relationship of seabass Lates calcarifer (Bloch) reared in a closed recirculating system. Israeli J. Aquac.-Bamidgeh, 53(3-4): 158-163.

Wedemeyer, G. A. 1997. Effects of rearing conditions on the health and physiological quality of fish in intensive culture. In: Iwama, G. K., Pickering, A. P., Sumpter, J. P. and Shreck, C. B. (Eds.), Fish stress and health in aquaculture, Cambridge University Press, Cambridge, p. 35-72. 